\title{
The Roles of The Kumamoto Muslim Community in Improving Halal Tourism Program in Kumamoto Prefecture Japan
}

\author{
Ichlasul Ayyub ${ }^{1}$, M. Mossadeq Bahri ${ }^{2}$, Kurniawaty Iskandar ${ }^{3}$ \\ \{ichlas29@gmail.com ${ }^{1}$; mossadeqbahri@gmail.com ${ }^{2}$; daradwipa@yahoo.com ${ }^{3}$ \} \\ ${ }^{1,2,3}$ School of Strategic and Global Studies, Universitas Indonesia, Depok, Indonesia
}

\begin{abstract}
Over the past few decades, Muslims have begun to show awareness about Islamic Sharia. Muslim tourists become interested in trying Halal tourism. The purpose of this study was to provide information about how the way Muslim life, especially about Halal travel. This study employed a qualitative approach, and data collection uses in-depth interviews with the chairman of the Muslim community in Kumamoto. The findings in this study emphasized the importance of the Muslim community to actively participate in socializing Halal Tourism with the community and Kumamoto authority. The conclusion in this study is that it is vital to create a good-minded Muslim. By showing such a nobility, the image of Islam and Muslims in a Muslim minority countries would be better. This research is expected to be a trigger for Muslims in the Islamic minority countries to become agents in improving the image of Islam in the world.
\end{abstract}

Keywords: Muslim Community, Muslim’s Image, Islam, Japan, Kumamoto Prefecture

\section{Introduction}

Islam is a religion with a development that has the most significant adherents in the world. The number of Muslims across the globe reaches 1.8 billion people, this number reaches almost a quarter of the total human population and will continue to grow. Islam has spread, and its adherents can be found in various countries, mostly Muslims or around 60\% in Asia, while in $20 \%$ in the Middle East, and the rest in North Africa. ${ }^{1}$ More than 300 million Muslims are in non-Muslim countries, including India which is the top 3 countries with the most significant number of Muslims, more Muslims in China than Muslims in Syria, Russia with more Muslims than Jordan and Libya, and also Japan, which has a Muslim population of around 190 thousand.

Islam is a minority religion in Japan. Islam entering Japan, along with the entry of Western Japanese ideas and beliefs in $1877 .^{2}$ Islam at that time was only known as a culture. But after 1890, Turkish ships anchored in Japan, to start diplomatic relations between the two countries, gave mutual understanding about each other's cultures, including Islam. After that, Islam is becoming known.

\footnotetext{
${ }^{1}$ Cornel University Library. (2017). Exhibition: Islam in Asia: Diversity in Past and Present: Muslim Populations. Accessed on 19 February 2019 11:03 from

http://guides.library.cornell.edu/IslamAsiaExhibit/MuslimPopulations

${ }^{2}$ Yusof, Shazlinda Md dan Shutto, Noriyuki. (2014). The Development of Halal Food Market in Japan:

An Exploratory Study. Malaysia: International Halal Conference
} 
The entry of knowledge about Islam gave rise to the desire of the Japanese to further explore the religion of Islam until finally, the desire to become followers of Islam emerged. The first followers of Islam in Japan were Mitsutaro Takaoka and Bumpachiro Ariga (1909) respectively, changing their names to Omar Yamaoka and Ahmad Ariga. The increasing number of Muslims in Japan began to build several places of worship, namely mosques. Japan's first mosque is Kobe Mosque that established in 1935.

The development of Islam in Japan significantly occurred during World War II and Oil Shock that struck Japan in 1973, since then, Islam began to be widely known (Yusof and Noriyuki, 2014: 2). Along with the emergence of these events, and the number of Muslim populations in Japan has increased dramatically, estimated at 190,000 people in 2010. Most of Muslim in Japan is immigrants, from Indonesia amounting to about 30,000 people, followed by Pakistan, Bangladesh, and Iran. There are very few Japanese Muslims, around 7,000 dominated by women married to male Muslim migrants. Most of the number of Muslims in Japan comes from abroad, which is about $90 \%$ of Muslims in Japan come from migrants.

Table 1. Percentage of Muslims in Japan

\begin{tabular}{llllll}
\hline Country & Indonesia & Bangladesh & Pakistan & Malaysia & Other \\
\hline Percentage & $36.1 \%$ & $16.3 \%$ & $11.6 \%$ & $5.5 \%$ & $30.5 \%$ \\
\hline
\end{tabular}

The table above shows the percentage of Muslims in Japan. Muslim migrants from Indonesia dominated that number at $36.1 \%$, followed by Bangladesh 16.3\%, Pakistan 11.6\%, Malaysia 5.5\%. While the other countries came from Turkey, Senegal, Sri Lanka, India, Ghana, Sudan, Morocco, UAE, Afghanistan, Saudi Arabia, Palestina, Xinjiang Uyghur, Niger, Jordan, and so on. ${ }^{3}$

The number of Japanese Muslims is increasing every year, although the number is not significant. Muslim residents in Japan, aside from migrants there are also Japanese nationality residents who convert to Islam. As the number of Muslim population in Japan grew, so began to appear business-friendly to Muslims, ranging from offices, lodging, and Halal travel agencies. This phenomenon is supported by the Japanese government's Halal Tourism program, which intends to attract a large number of Muslim tourists to visit Japan.

\subsection{Halal Tourism}

Over the past few decades, Muslims have begun to show increased awareness and demand for products and services that are following Islamic Sharia from food, medicine, clothing, cosmetics, to travel services. This demand has encouraged global producers to make many Halal products. The development of this Halal product has given rise to Halal consumers and Halal certification industries with a more comprehensive Halal range.

The current Halal wave has moved beyond its medieval bases in Baghdad, Cairo, Istanbul, to later include Kuala Lumpur, Jakarta, Singapore, London, and Chicago. Muslims living in Europe and North America have higher of income and high awareness of their religious

\footnotetext{
${ }^{3}$ Becoming Legally Japanese. (2013). Can Muslims Acquire Japanese Citizenship/Nationality or Permanent Residency? accessed on 29 March 2018 from http://www.turning-japanese.info/2013/10/canMuslims-acquire-japanese.html
} 
identity. ${ }^{4}$ A desire arises in a Muslim to live a modern and cosmopolitan life and be free to engage in contemporary consumption habits, from buying the most fashionable and trendy clothes to eating in expensive restaurants, while shopping for products that allow them to meet high standards. Broad conceptualization of Muslims about Halal, as in the case of food, organic, unsullied, healthy, and delicious, has attracted the attention of global producers who want to benefit from this market. Whereas in the case of tourism, the conceptualization of Muslims regarding Halal can be in the form of the availability of worship facilities, a unique schedule is provided for worship in the tourism travel agenda, to eating and drinking in restaurants that are Halal certified.

Understanding Halal itself is something that is justified or allowed. Halal words originate from Arabic words, namely halla, yahillu, hillan, wahallalan, which intend to be defended or permitted by sharia law. In Al-Munjid, Halal is something that is allowed by Allah SWT. According to the Dictionary of the Council in Malaysia, Halal intends to justify something done (in Islam), permitted (not prevented by sharak), licensed, defended. ${ }^{5}$ Something is considered Halal in Islam as long as no proof shows that it is Haram. In this connection, the scope of Halal in Islam is not only based on food and goods but also covers a vast field that encompasses all aspects of human life, including in terms of tourism.

Humans like to travel to a destination, with varied objectives. In determining its purpose, there are several criteria that must be considered; this also applies to a Muslim. When a Muslim travels to a place outside the Islamic world, he must always defended his religion. This rule covers many things, one of which concerns food and drinks. Islamic teachings have a standard and criteria in terms of food; the standart is called Halal. Halal comes from Arabic, which means "permitted". ${ }^{6}$ Halal refers to the eating habits of Muslims, which regulated in the Sharia law. Halal is everything that must be consumed by Muslims. Halal is not only limited to food and drink but also for daily life and behavior of a Muslim more broadly. Opponent of Halal is Haram, which means anything that is prohibited or 'illegitimate' or 'prohibited', such as eating pork and intoxicating drinks.

Actions that are prohibited in the teachings of Islam are called Haram acts, for example, fraud, theft, murder until leaving Islam is illegal behavior. In terms of food, Halal guarantees healthy and hygienic food. To ensure whether the food is Halal or not, it is necessary to have an institution that conducts or issues Halal certificates. Halal Certificate is a certificate that ensures that the food and may be eaten (Halal).

The product must undergo a rigorous and extensive inspection conducted by a Halal certification agency, one of the institutions that handle Halal certificates in Indonesia is the Indonesian Ulema Council (MUI). Products that pass the Halal inspection, the manufacturer of the product will receive a Halal certification, has the right to embed a Halal sign or stamp on the product packaging, until it is allowed to be mass-produced.

At present, the concept of Halal is not only limited to food production and consumption, but also extends to the banking system, medicine products, cosmetics, lifestyle products such as clothing, service products such as tourism or travel, and so forth. Economically, the growth of the Muslim population in the world has produced unique opportunities for the development of

\footnotetext{
${ }^{4}$ Armanios, Febe. Ergene, Bogac. (2018). Halal Food: A History. Inggris: Oxford University Press

${ }^{5}$ Saleh, Arif bin Rosman dan Liza, Aemy bin Minhat. (2012). Konsep Halal Dan Toyyib Menurut AlQuran: Kajian Tematik terhadap Kitab Tafsir At-Tobari dan Al-Qurtubi. WCIT 2012: 1st World Conference on Islamic Thought \& Civilization 1

${ }^{6}$ Adidaya, Yosa Ahmad. (2016). Halal in Japan: History, Issues, and Problems. Norwegia: University of Oslo.
} 
the Halal industry. Muslims consider Islam as a way of life and self-identity. When a Muslim identifies himself as someone who follows the teachings of Islam, then he must show specific behavior to show his faith. For example, consuming only food that is permitted (Halal) and avoiding things that are forbidden (Haram) is one way for Muslims to show their faith. Such life practices create an environment where Halal products are needed for Muslims, even when they are not in a Muslim society, such as when in a non-Muslim country. Therefore, Muslim-friendly products and services have begun to appear in foreign countries.

At this time, the hospitality service business and services that are following Islamic Sharia are developing rapidly in the Islamic tourism industry. Services such as transportation, lodging, and entertainment that are following Sharia are growing quickly in foreign countries. But until now, the discussion about the concepts, characteristics, and requirements of Sharia services is still not significant. There are no specific definitions regarding Sharia services.

In general, Sharia services is a hospitality that are following Islamic law, such as hotels that provide facilities for Muslim guests. Hotel that have Sharia services usually provide prayer mats, qibla signs, ablution facilities, prayer rooms (musolla), and many goods that Muslim need. ${ }^{7}$ Resorts and health centers that only cater to Muslim men or only women-only spas that distinguish gender, and others. Although Sharia services have been found in many countries; in terms of operations and management, there are no standards or guidelines that can be used as a benchmark; this causes business people to have doubts about starting to explore this market. However, this has not become an obstacle because of the enormous market value of this Muslim.

\begin{tabular}{|lc|}
\hline $\begin{array}{l}\text { Global Muslim Consumer Spending on Food and Lifestyle Sectors } \\
\text { Sector }\end{array}$ & $\begin{array}{c}\text { Existing Muslim Market (2014, USD billions) } \\
\text { Global Muslim food and lifestyle }\end{array}$ \\
sector expenditures & $\$ 1808$ \\
Food & $\$ 1128$ \\
Fashion & $\$ 230$ \\
Tourism & $\$ 142$ \\
Cosmetics & $\$ 54$ \\
Pharmaceuticals & $\$ 75$ \\
Media and recreation & $\$ 179$ \\
\hline
\end{tabular}

Fig. 1. Table of Muslim Consumer Expenditures in the Food and Lifestyle Sector

From the picture above, it can be seen that Muslim consumers are a promising market. In 2014, the Muslim market in food and lifestyle was worth about $\$ 1.8$ trillion. ${ }^{8}$ The Muslim food market is worth around 1.1 trillion dollars, while tourism alone is worth around 140 million

\footnotetext{
${ }^{7}$ Khadijah, Siti Ab. Manan. Abd Rahman, Fadilah. Sahri, Mardhiyyah. (2014). Contemporary Issues and Development in the Global Halal Industry: Selected Papers from the International Halal Conference 2014. Singapore: Springer.

${ }^{8}$ Nadeem Riaz, Mian. Munir Chaudry, Muhammad. (2019). Handbook of Halal Food Production. New York: CRC Press
} 
dollars. Recent data estimates that global Muslim spending on the lifestyle sector reaches US \$ 2.1 trillion in 2017, while the Islamic financial industry has a total asset of around US \$ 2.4 trillion. Muslim spending in the food and beverage category has the highest value, which is about US \$ 1.3 trillion; followed by clothing and fashion valued at US $\$ 270$ billion; media and entertainment US \$ 209 billion; business travel or tourism US \$ 177 billion; pharmaceutical products valued at US \$87; and cosmetic products US \$ 61 billion (See figure 1.2).

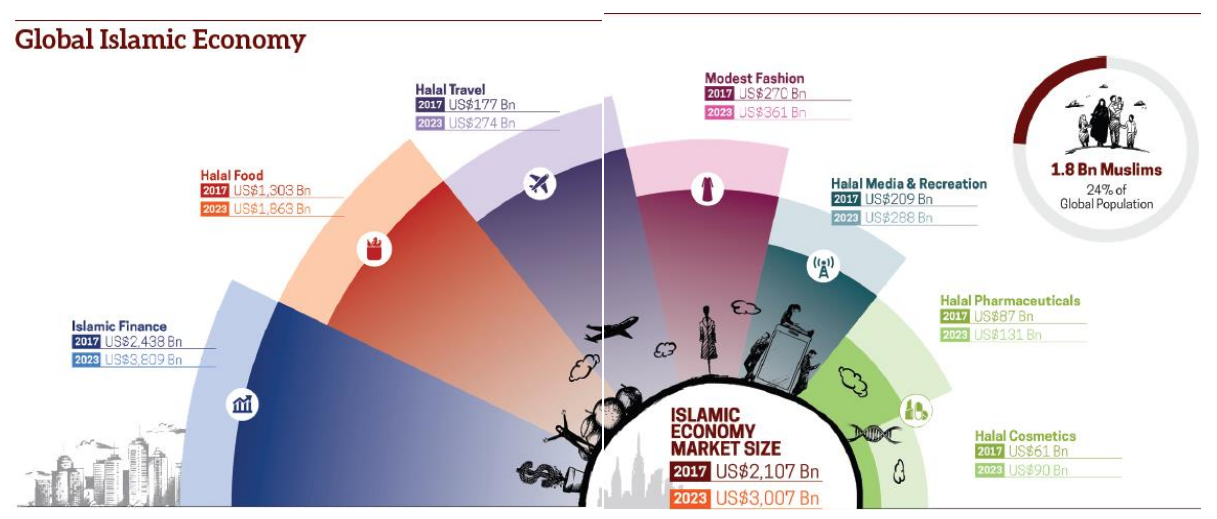

Fig. 2. Global Islamic Economy

The size of the Muslim market above makes businesspeople compete to make Muslimfriendly products. They are starting from Halal certified food and beverage products, Islamic finance or Islamic Finance, Halal travel, fashion and fashion products, Halal media and recreation, to Halal medicines and cosmetics. For tourism products or Halal travel alone, expenses incurred by Muslims for travel are US \$ 177 billion in 2017 and are expected to reach US \$ 274 billion in 2023. ${ }^{9}$

Along with the increasing Muslim consumer market and the large number of followers of Islam, various countries began to be interested in competing in the Halal market. Not only Muslim-majority countries, many non-Muslim countries also began to be involved in developing a Halal business, one of which is Japan. Japan is currently actively making policies that support Muslims. The government makes Japan a Halal tourist destination; it is expected to be able to lift Japan's domestic economy. Japanese government must improve worship facilities and open Halal restaurants in Japan; in addition, business people in Japan must provides Halal lodgings, and other Halal services to give hospitality to Muslims who want to travel, work or look for study in Japan. It can be said that Japan is currently using a religious approach to attract tourists, students, and workers, mainly from Islamic countries.

Japan is a non-Muslim country with a significant development of the Halal industry. However, compared to other East Asian countries, Japan is late in developing the Halal market due to a lack of interest in religion in Japanese society..$^{10}$ In Japan, followers of Islam only make up about 0.18 percent of the total population, a small population making Muslims often feel distressed in maintaining their belief in Japan. Despite its slow development, the concept of

\footnotetext{
9 Ibid

${ }^{10}$ Ibid
} 
Halal is starting to become a topic of new trends in Japan. Given that Tokyo was chosen to host the Olympics and Paralympics in 2020, Japan must be able to handle the demands of visitors from different countries and cultures, including among Muslims, this is because Muslims are one of the largest communities in the world, which is about 1.8 billion people spread across the globe.

The concept of Halal has begun to be discussed in many local newspapers, and not a few local TV stations that make programs about Halal in Japan. Halal in Japan does not only focus on the basic daily needs of Muslims. Halal can cover additional needs such as lodging, cosmetics, and so on. Therefore Halal is a lucrative market for Japanese business people.

Along with the increasingly cheap travel tickets to Japan, and visa exemptions for several countries, the number of Japanese visitors has increased, including Muslim visitors. This conditions also has an impact on increasing the number of Halal food providers in Japan. However, there is a big problem for Muslim tourists in Japan, which is the first language barrier. ${ }^{11}$ Most of food packaging use making it difficult for tourists to understand and judge whether the product can be eaten or not for Muslim. To overcome the language barrier, not a few Muslims in Japan will bring their food from home, then if you want to try to experience the experience of trying local cuisine or spending money to buy local Japanese food. Then they must rely on a guide/friend who can speak Japanese who can help with translation. Traveling in Ramadan will cause other problems because there are still few hotels that do not provide food early for dawn. Besides, there is also a lack of fulfillment of necessary Muslim facilities such as a family-friendly travel environment, facilities for taking ablution water, etc.

To overcome some of the problems mentioned above, several non-profit organizations have been formed by the Japanese goverment; there is the Japan Halal Association (JHA), which provides the certification of Halal food and other products. JHA also carries out campaigns to provide places for Muslim prayer services. JHA uses the Department of Islamic Development Malaysia standard (JAKIM) in helping Japanese food producers/outlets to get Halal certification. Also, JHA gives training and certification for people who deal with Halal in Japanese companies. ${ }^{12}$ The establishment of a non-profit organization such as JHA has encouraged several travel agents in Japan to launch Halal tour packages for Muslim tourists based in Tokyo and Osaka.

\subsection{Muslim Community in Japan}

Islam continues to develop in Japan, its adherents are increasing every year, and Muslim communities in Japan have begun to emerge. Muslims make a community that can be a place to share stories and as a means of communication between Muslims in Japan. Community comes from the Latin community which means "similarity," then becomes communis, which means "equal, public, shared by all or many." A community is a social group of several individuals that have the same environment, interests and habitats. The individuals within it can have intentions, risks, preferences, beliefs, resources, needs, and many other similar conditions. Soenarno (2002) defines community as an identification and social interaction that is built with various dimensions of functional needs. ${ }^{13}$ Meanwhile, according to Kertajaya Hermawan (2008), a community is a group of people who have a close personal relationship between the members, and have the same interests or values. ${ }^{14}$ In the case of Muslims in Japan, along with the large

${ }^{11}$ Ibid

${ }^{12}$ Ibid

${ }^{13}$ Soenarno, (2002). Kekuatan Komunitas Sebagai Pilar Pembangunan Nasional. Jakarta.

${ }^{14}$ Hermawan, Kertajaya. 2008. Arti Komunitas. Jakarta: Gramedia Pustaka. 
Muslim population, began to form several Muslim communities. One Muslim community is in the Kumamoto Islamic Center (KIC). Kumamoto Islamic Center is a Muslim organization in Kumamoto Prefecture Japan, members of this organization come from various countries, including from Indonesia, Egypt, Bangladesh, Afghanistan, Malasia, Barbecue, Nigeria, Sudan, Pakistan, and others.

The organization or community, as mentioned earlier, namely KIC, whose members consist of many individuals, each of whom has its role in the community. Role theory states that a role is a group of behaviors associated with a particular position. Different roles make different types of behavior. However, what makes the action appropriate in one situation and not in another condition is relatively free for someone who plays that role. ${ }^{15}$ The role is a dynamic aspect in the form of an action or behavior carried out by someone who occupies a particular position or position and exercises rights and obligations following his position. If someone can carry out that role properly, then someone will hope that what is carried out according to the wishes of their environment.

The role in an institution is related to the duties and functions, namely two things that can not be separated in the implementation of work by a person or institution. ${ }^{16}$ The task is a set of fields of work that must be done and attached to a person or institution following the functions they have. The purpose of an institution or formal institution is the existence of power in the form of rights and duties own by a person in his position in the organization to do something following their respective fields of responsibility and authority. The function of the institution is structured as a guide for an organization to carrying out activities and achieving organizational goals. JHA has the role to provides Halal certification for food outlets or other industry in Japan. JHA has a significant role in the development of the Halal market in Japan. Similarly, the Japan Halal Tourism Program which requires the role of individuals and groups of individuals so that this program can be achieved. Not only the government, community workers are also needed in the success of this program, including the Muslim community. Muslim communities or organizations have a role in Japan's Halal Tourism program; for example, in conducting campaigns about the definition of Halal itself. Japanese people are still unfamiliar with Islam and the concept of Halal. Therefore the Muslim community in Japan is expected to have a significant role in spreading understanding about Islam, especially regarding Halal.

\section{Methods}

This study uses a constructivist worldview. Constructivism is considered an approach to qualitative research. Constructivists believe that each individual always tries to understand the world in which they live. ${ }^{17}$ This research is a qualitative research, according to Sugiyono (2017) qualitative research departs from a problem that is dim, temporary, tentative, and can develop after researchers are in the field. ${ }^{18}$ Problems that develop here can mean expanding or becoming deeper, even issues in qualitative research can change totally or change.

A qualitative research always determine their research-based on many social situation under study, including aspects of places, actors, and activities that are synergistically interconnected. ${ }^{19}$

\footnotetext{
${ }^{15}$ Soekanto, Soerjono. (2002). Sosiologi Suatu Pengantar. Jakarta: Rajawali Press.

${ }^{16}$ Himawan, Muammar. (2004). Pokok-Pokok Organisasi Modern. Jakarta: Bina Ilmu.

${ }^{17}$ Creswell, John W. (2016). Research Design, Pendekatan Metode Kualitatif, Kuantitatif, Dan

Campuran. Yogyakarta: Pustaka Pelajar

${ }^{18}$ Sugiyono. (2017). Metode Penelitian Kuantitatif, Kualitatif dan R\&D. Bandung: Alfabeta.

${ }^{19}$ Ibid
} 
The reason this study uses qualitative research methods is because the researcher wants to obtain a holistic view regarding the development of the Halal Tourism program in Kumamoto City, and how the role of the local Muslim community towards the program. This research is conducted by carefully recording all phenomena or symptoms that are seen, heard, and read through interviews, field notes, official documents, etc., and researchers must compare, combine, abstract, to draw conclusions. ${ }^{20}$

The author in this study uses a case study research design. Case studies are carried out by developing an in-depth analysis of a case, event, process, activity of one or more individuals. ${ }^{21}$ The author uses a case study research design because with this research design, the author can gain a deeper and more complete understanding of how the development of the Halal Tourism program in Kumamoto City, Japan. Besides, this research also explains how the role of the local Muslim community for the program.

\section{Results}

Japanese society, especially Kumamoto people, have diverse views about Islam, some know but do not care, some look negative, and some even do not know what Islam is. Most of the people of Kumamoto view the religion of Islam negatively. This phenomenon is caused by several factors, such as the number of adverse reports about Islam, to Japanese people who are not too fond of different beliefs or religions. The negative view of the Kumamoto people towards Islam arose after the twin tower attack terrorist incident that occurred on 11 September 2001 in the United States. Before the twin tower terror attacks in the United States, the negative view of the Kumamoto people towards foreign religions, especially Islam, had emerged after the Sarin gas terrorist attack on the Tokyo subway. The terror attack occurred on March 20 1995; the attack was carried out by adherents of the religion of Aum Shinrikyo. Aum Shinrikyo was led by Shoko Asahara, a person from Kumamoto. Therefore the Kumamoto people became a little afraid of the existence of foreign religions. The series of terror attacks carried out by unscrupulous religious adherents, especially Islam, made security by Kumamoto security officers, especially against Muslims. This is the case with MS informants; he said that after the twin tower terror attacks he was always watched by the police. "Every behavior of Muslims, not only me, Muslims who are Egyptians, are always followed" (MS, 45 years). But thanks to the efforts of the adherents of Islam from various countries who live in Kumamoto, the Kumamoto people's views on Islam are gradually getting better. They want to be open to the Muslim community. The followers of Islam in Kumamoto are mostly from foreigners who work or study in Kumamoto. The longer the number of Muslims in Kumamoto is increasing.

\section{Discussion}

Every member of a community has their respective roles, including the Kumamoto Muslim community. The Muslim community is the face of Muslim countries. Muslims must be a good example for the surrounding community. A good Muslim is the most useful Muslim for the community. As was done by the Muslim community in Kumamoto. Although initially members

${ }^{20}$ Bungin, Burhan. (2008). Metodologi Penelitian Kualitatif. Jakarta: Raja Grafindo Persada.

21 Ibid 
of the Muslim community often received unfavorable treatment from the local community, thanks to patience and hard work, the community eventually melted and was willing to accept Muslims to live in Kumamoto. After the Kumamoto Mosque was built, the activities of the Muslim community often caught the attention of Japanese residents. In addition to holding the five-time prayer, Kumamoto Mosque also conducts educational programs for the surrounding community, such as opening English and Arabic classes. Besides, the Kumamoto Muslim community often helps the surrounding community in the event of an emergency, such as an earthquake. During the 2016 earthquake in Kumamoto, transportation lines were cut off; food supplies were running low until finally, many Kumamoto people decided to flee Kumamoto. The Muslim community in Japan, when they got word of a Muslim brother who had been struck by a disaster, immediately rushed to assist. The large amount of assistance that came from Muslim communities throughout Japan, made the Kumamoto mosque caretaker begin to channel the aid received to be distributed to residents in need. Although at first, no one accepted, after some efforts, finally, the community around the mosque was willing to take assistance from the Kumamoto Muslim community.

After the Kumamoto earthquake, the name of the Kumamoto community was increasingly recognized by the people not only in Kumamoto but throughout Japan. The Kumamoto community is often invited to various events, such as seminars, television shows, and so on. The improved image has made the Kumamoto government more concerned with the Muslim community. The Kumamoto government often invites the Kumamoto Muslim community to participate in activities held by the Kumamoto government. From there began programs that could support the needs of Muslims in Kumamoto. Starting from the provision of restaurants, shops, and Halal lodging

\section{Conclusion}

The Kumamoto Halal Tourism Program requires the role of individuals and groups of individuals for this program to be achieved. Not only the government, support from the community is also needed in the success of this program, including the Muslim community. Muslim communities or organizations have a role in Japan's Halal Tourism program, for example, in conducting campaigns about the definition of Halal itself. Japanese people are still unfamiliar with Islam and the concept of Halal. Therefore the Muslim community in Japan is expected to have a significant role in spreading understanding about Islam, especially regarding Halal.

\section{References}

[1] Adidaya, Yosa Ahmad. (2016). Halal in Japan: History, Issues, and Problems. Norwegia: University of Oslo.

[2] Armanios, Febe. Ergene, Bogac. (2018). Halal Food: A History. Inggris: Oxford University Press

[3] Becoming Legally Japanese. (2013). Can Muslims Acquire Japanese Citizenship/Nationality or Permanent Residency? accessed on 29 March 2018 from http://www.turningjapanese.info/2013/10/can-Muslims-acquire-japanese.html

[4] Bungin, Burhan. (2008). Metodologi Penelitian Kualitatif. Jakarta: Raja Grafindo Persada. 
[5] Cornel University Library. (2017). Exhibition: Islam in Asia: Diversity in Past and Present: Muslim Populations. Accessed on 19 February 2019 11:03 from http://guides.library.cornell.edu/IslamAsiaExhibit/MuslimPopulations.

[6] Creswell, John W. (2016). Research Design, Pendekatan Metode Kualitatif, Kuantitatif, Dan Campuran. Yogyakarta: Pustaka Pelajar

[7] Danim, Sudarwan. (2002). Menjadi Peneliti kualitatif. Bandung: Pustaka Setia.

[8] Dinar Standart. (2018). State of the Global Islamic Economy Report 2018/19. From https://haladinar.io/hdn/doc/report2018.pdf. Accessed on 20 May 2019.

[9] Fandi Tjiptono. (1997). Strategi Pemasaran. Edisi kedua. Yogyakarta: Andi offset.

[10] Fathil, Fauziah \& Fathil, Fathiah. (2011). Islam in Minority Muslim Countries: A Case Study on Japan and Korea. World Journal of Islamic History and Civilization, 1 (2): 130-141, 2011.

[11] Fischer, Johan. (2011). The Halal Frontier Muslim Consumers in a Globalized Market. Amerika Serikat: Palgrave Macmillan.

[12] Fuad, Zaki. (2014). Pariwisata Dalam Perspektif Islam. Accessed on 12 May 2018 from http://www.acehtourism.info/id/pariwisata-dalam-perspektif-islam/

[13] Guichard-anguis, Laboratoire 'es Sylvie. Moon, Okpyo. (2009). Japanese Tourism and Travel Culture (Japan Anthropology Workshop). New York: Routledge.

[14] Hermawan, Kertajaya. 2008. Arti Komunitas. Jakarta: Gramedia Pustaka.

[15] Himawan, Muammar. (2004). Pokok-Pokok Organisasi Modern. Jakarta: Bina Ilmu.

[16] Inoue, Eido. (2013). Can Muslims acquire Japanese citizenship/nationality or permanent residency? Accessed on 11 May 2018 from http://www.turning-japanese.info/2013/10/can-Muslimsacquire-japanese.html

[17] Jafari, Jafar \& Scott, Noel. (2014). Muslim World and Its Tourisms. Annals of Tourism Research 44 (2014) 1-19.

[18] Jamal, Ahmad. Raj, Razaq. Griffin, Kevin A. (2019). Islamic Tourism: Management of Travel Destinations. Inggris: CABI.

[19] Kasmon, Muhamad Nordin. (2011). Konsep kosher dalam agama Yahudi analisis menurut perspektif pemikiran hukum Islam Muhamad Nordin bin Kasmon. Masters thesis, University of Malaya)

[20] Khadijah, Siti Ab. Manan. Abd Rahman, Fadilah. Sahri, Mardhiyyah. (2014). Contemporary Issues and Development in the Global Halal Industry: Selected Papers from the International Halal Conference 2014. Singapore: Springer.

[21] Kotler, Philip. (2005). Manajemen Pemasaran, Jilid I dan II. Jakarta: PT. Indeks.

[22] Kyoto Muslim Association. (2019). Muslim Friendly Kyoto. Accessed on 20 May 2019 from https://kyoto.travel/en/muslim)

[23] Muhammad Hashim, Nurhidayat. Nafhatun Md Shariff, Nur. Fatahiah Mahamood, Siti. Musa Fathullah Harun, Hanifah. Solahuddin Shahruddin, Mohd. Bhari, Azri. Dkk. (2018). Proceedings of the 3rd International Halal Conference (INHAC 2016). Singapore: Springer.

[24] Moleong, Lexy J. (2017). Metodologi Penelitian Kualitatif. Bandung: Remaja Rosdakarya.

[25] Nadeem Riaz, Mian. Munir Chaudry, Muhammad. (2019). Handbook of Halal Food Production. New York: CRC Press.

[26] Oktadiana, Hera, Pearce Philip L. Chon, Kaye. (2016). Muslim Travellers' Needs: What Don't We Know? Tourism Management Perspectives 20 (2016) 124-130.

[27] Ranking Web of University. (2018). Asia. Accessed on 29 March 2018 from http://www.webometrics.info/en/Asia

[28] Saleh, Arif bin Rosman dan Liza, Aemy bin Minhat. (2012). Konsep Halal Dan Toyyib Menurut Al-Quran: Kajian Tematik terhadap Kitab Tafsir At-Tobari dan Al-Qurtubi. WCIT 2012: 1st World Conference on Islamic Thought \& Civilization 1

[29] Soekanto, Soerjono. (2002). Sosiologi Suatu Pengantar. Jakarta: Rajawali Press.

[30] Soenarno, (2002). Kekuatan Komunitas Sebagai Pilar Pembangunan Nasional. Jakarta

[31] Sukmadinata, Nana Syaodih. (2005). Metode Penelitian Pendidikan. Bandung: Remaja Rosda Karya.

[32] Sugiyono. (2017). Metode Penelitian Kuantitatif, Kualitatif dan R\&D. Bandung: Alfabeta. 
[33] Susilo, Ricard. (2018). Jumlah Tenaga Kerja Asing di Jepang Mencapai 1.27 Juta Jiwa Paling Banyak Orang China. Accessed on 19 February 2018 from http://www.tribunnews.com/internasional/2018/01/27/jumlah-tenaga-kerja-asing-di-jepang-mencapai127-juta-jiwa-paling-banyak-orang-china

[34] Sutopo, H. 2006. Metode Penelitian Kualitatif. Surakarta: UNS Press.

[35] Yusof, Shazlinda Md dan Shutto, Noriyuki. (2014). The Development of Halal Food Market in Japan: An Exploratory Study. Malaysia: International Halal Conference.

[36] Zulham. (2018). Peran Negara dalam Perlindungan Konsumen Muslim terhadap Produk Halal. Jakarta: Kencana 